\title{
NEW SPECIES OF THE GENUS CAMARICUS THORELL, 1887 (ARANEAE : THOMISIDAE) FROM BANGLADESH
}

\author{
Vivekanand Biswas* and D. Raychaudhuri ${ }^{1}$ \\ Department of Zoology, Khulna Govt. Womens' College, \\ Khulna-9000, Bangladesh
}

\begin{abstract}
A study on the crab-spiders was carried out from different areas of Bangladesh. Two species of the genus Camaricus Thorell were recorded during the study, of which one species Camaricus chayani nov. sp. is reported to be new to science and other one C. formosus Thorell is a new record for the area of present study. The paper contains generic diagnosis, illustrated description and distribution together with key to the species.
\end{abstract}

Key words: Crab-spiders, Araneae, Thomisidae, Camaricus, Bangladesh

\section{INTRODUCTION}

Crab-spiders of the genus Camaricus Thorell are common predatory members in the gardens and forests of Bangladesh. They do not make any web and hide themselves under flower or leaves of plants for the preys, holding the 1 st pair of legs wide apart. They can show a remarkable degree of camouflage or mimicry. The genus was first established by Thorell in 1887 with the typespecies C. maugei (Walckenaer 1837) and is represented by 14 species worldwide (Platnik 2016). In Bangladesh, the genus contains only one species (Chowdhury and Nagari 1981, Chowdhury and Pal 1984, Okuma et al. 1993, Biswas et al. 1993, Begum and Biswas 1997, Biswas 2009, Biswas and Raychaudhuri 2003). On the other hand, several species of the genus have been reported from India and other Asian countries (Tikader 1980, Tikader and Biswas 1981, Gajbe and Gajbe 2000, Majumder 2005, Saha and Raychaudhuri 2007, Keswani et al. 2012, Sen et al. 2015, Chen and Zhang 1991, Zhao 1993, Song and Zhu 1997, Song et al. 1999, Yaginuma 1986, Ono 1988, Paik 1978, Barrion and Litsinger 1995, Kim and Gwon 2001, Namkung 2003).

The present paper describes two species of crab-spiders of the genus Camaricus Thorell, namely - C. formosus Thorell and C. chayani nov. sp. of which C. chayani is new to science. Both the species are described and illustrated together with the generic diagnosis and key to the species.

*Author for correspondence: vivekarach@gmail.com ${ }^{1}$ Entomology Laboratory, Department of Zoology, Calcutta University 35, Ballygunge Circular, Road, Kolkata-700 019, India. 


\section{MATERIAL AND METHODS}

The study was made with the collection of spiders from different gardens and forest areas of Bangladesh from April, 1997 to December, 2001. The collected areas were the localities of Bagerhat, Khulna, Jessore, Jhenidah and Faridpur districts. The collected places were Dashani, Kachua and Morelganj of district Bagerhat, Elaipur of Khulna, Khajura and Keshabpur Jessore, Sikarpur of Jhenaidah and Agricultural Diploma Institute (ADI) campus district Faridpur. The collecting methods were made following Tikader (1987) and were as follows:

The spiders were collected by hand, hand-picking vials and by shaking the branches of trees on an inverted umbrella placed underneath the bushes and trees (Tikader 1987). The collected specimens were anesthesized using chloroform and were then transferred to a Petri dish filled with $70 \%$ ethyl alcohol for sorting (Biswas and Raychaudhuri 2015).

Immediately after sorting, the spiders were brought to the laboratory and were thus kept 3 - 4 hours for relaxation of body muscles. The body parts (e.g. legs, pedipalps etc.) were then stretched by using fine brushes, needles, pair of forceps etc. within alcohol-filled petridishes. The ready specimens were then preserved as per Lincoln and Sheals (1979).

Spiders thus preserved were identified following Pocock (1900), Schick (1965), Tikader (1980, 1987), Majumder (2005), Dondale and Redner (1978), Barrion and Litsinger (1995), Song and Zhu (1997), Song et al. (1999), Chen and Zhang (1991), Yaginuma (1986), Kim and Lee (2012) and Sen et al. (2015). The identity of the species were later confirmed with the Zoological Survey of India, Kolkata.

The identified types are at present in the collections of the Department of Zoology, Khulna Government Womens' College, Khulna and will be deposited to the Museum of the Department of Zoology, University of Dhaka, Bangladesh in due course of time. For new species description, the specimen deposit number should be included for future reference.

The specimens or its body-parts were arranged in a cavity block filled with alcohol plus sand beach on the stage of a stereo binocular microscope. The male pedipalps and female epigynum were dissected out on this position with fine blade or skulpel. The epigynum was cleared in clove oil for 6-12 hours and was studied under binocular microscope. After study, it was kept permanently in a microvial and placed together with the holotype in the same vial within Audman's preservative.

The male pedipalps, after separate out from the body, were boiled in $10 \%$ $\mathrm{KOH}$ solution for 5 - 10 minutes. After expansion of its different parts, it was 
studied under binocular microscope. Like epigynum, the male palps were also preserved with male spider in Audman's preservative permanently.

The illustrations of the body parts were made with the help of Camera Lucida fitted with stereo binocular microscope (SV8, Zeiss). The photographs were taken in the laboratory with the Camera fitted in stereo binocular microscope. All the measurements of different body parts were taken in millimeters $(\mathrm{mm})$.

\section{OBSERVATIONS AND RESULTS TAXONOMY}

Family: Thomisidae Sundevall, 1833

Genus :Camaricus Thorell, 1887

Type-species : C. maugei Walckenaer

1887. Camaricus Thorell, Ann. Mus. civ. Stor. Nat. Gen. 5(2) : 261.

1895. Camaricus : Simon, Histoire Nat. Araignees, Paris 1(4) : 1012.

1954. Camaricus : Roewer, Catalogue der Araneae, Belgique 2 : 830.

1980. Camaricus : Tikader, Fauna of India, Thomisidae 1(1) : 174.

1988. Camaricus: Ono, Bull. Natn. Sci. Mus., Tokyo: 220.

1995. Camaricus : Barrion \& Litsinger, Riceland spiders South \& S.east Asia : 237

1997. Camaricus : Platnick, Advances in Spider Taxonomy: 824.

1997. Camaricus : Song \& Zhu, Fauna Sinica, Thomisidae 35: 173.

2005. Camaricus : Majumder, Memoirs Zool. Surv. India 20(3): 50.

2016. Camaricus : Platnick, World spider catalog, version 16.0: 2586.

Diagnosis: Spiders of this genus usually are medium in size. Cephalothorax moderately high, wider in front, sides nearly parallel and clothed with hairs. Eyes in 2 rows; both rows recurved; median eyes nearer to the laterals. All members of this genus are crab-like in appearance and with nice metallic colours.

Abdomen broad, decorated, nicely coloured and decorated, clothed with fine hairs.

Biological note: Spiders of the genus Camaricus are slow in movement. They cannot spin any web but sometimes can make typical nests under the leaves or branches of trees from where they catch their preys. They are usually found on the coloured flowers and green leaves of plants. They show a remarkable degree of camouflage or mimicry and are good predators of insect pests in the garden and forests.

Distribution: Asia, America, Africa. 


\section{Key to the species}

1. Cephalothorax with a deeply distinct fovea; clypeus straight; abdomen globose, posteriorly never produced; chelicerae robust, with 5 and 2 teeth on inner and outer margins respectively; sternum robust, anterioirly broad, with anterior margin weakly concave; epigyne as in Fig. 1e; male palp as in Fig. $1 \mathrm{f}$

formosus

- Cephalothorax devoid of fovea; clypeus covex, medially notched; abdomen elongately globose, posteriorly little produced; chelicerae strong with 1 tooth on each of inner and outer margin; sternum never robust, elongate, anteriorly broad with anterior margin deeply concave; epigyne as in Fig. 2, e

chayani nov. sp

\section{Camaricus formosus Thorell (Figs 1a-f)}

1887. Camaricus formosus Thorell, Ann. Mus. civ. Gen.: 261.

1980. Camaricus formosus : Tikader, Fauna of India, Thomisidae 1(1): 175.

1995. Camaricus formosus : Barrion \& Litsinger, Riceland spiders of South \& Southeast Asia: 238.

1997. Camaricus formosus : Platnick, Advances in Spider Taxonomy: 824.

1997. Camaricus formosus : Song \& Zhu, Fauna Sinica, Thomisidae 35: 173.

2004. Camaricus formosus : Majumder, Mem. Zool. Surv. India 20(2): 39.

2009. Camaricus formosus : Biswas: In: Ahmed (ed.), Flora \& Fauna Bangladesh, Arachnida 18(1): 346.

2016. Camaricus formosus : Platnick, World spider Catalog, version 16.0, http:// research.amnh.org/iz/spiders/catalog/intro.html

Material examined: 1 female, 1 male, Bagerhat, 19. IX. 1992, Coll. V. Biswas; 1 female, ADI, Faridpur, 04. IV. 1991, Coll. V. Biswas; 1 female, Shikerpur, Jhenidah, 12. VIII. 1993, Coll. V. Biswas ; 2 female, Jessore, 08. VII. 1992, Coll. V. Biswas, 1 male, 1 female, Daulatpur, Khulna, 07.VII. 1993, Coll. V. Biswas.

General: Cephalothorax nearly red; legs greenish; abdomen dorsally dark brown and ventrally greenish. Total body length (female) $7.50 \mathrm{~mm}$. Carapace $3.00 \mathrm{~mm}$ long, $2.50 \mathrm{~mm}$ wide; abdomen $4.50 \mathrm{~mm}$ long and $4.00 \mathrm{~mm}$ wide. Total body length (male) $6.00 \mathrm{~mm}$. Carapace $2.30 \mathrm{~mm}$ long, $2.00 \mathrm{~mm}$ wide; abdomen $3.70 \mathrm{~mm}$ long and $4.00 \mathrm{~mm}$ wide. 


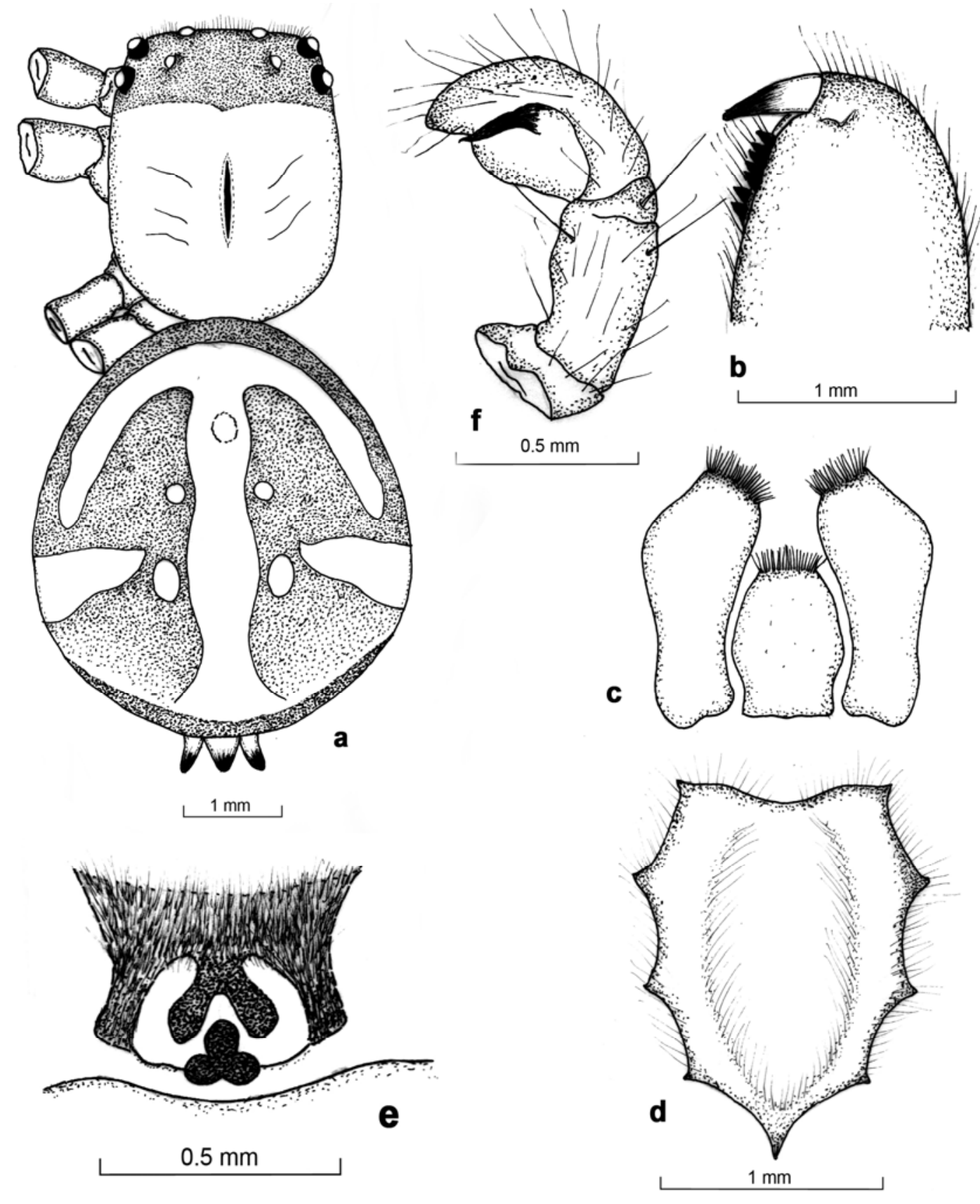

Fig. 1. Camaricus formosus Thorell. a. Dorsal view; b. Chelicerae; c. Maxillae and labium; d. Sternum; e. Epigynum and f. Male palp. 
Cephalothorax: Anteriorly black and posteriorly red, nearly square, slightly convex dorsally. Both row of eyes recurved; antero and posterolateral eyes larger, nearly close and basally with black patches; ocular quad wider than long and narrowing anteriorly; postero-median eyes widely placed; centre of thoracic region with a deep conspicuous fovea; radii distinct. Chelicerae broad, basally wide, outer margin with 2 and inner margin with 4 closely placed teeth, fang short and thick, covered with hairs and spines (Fig. 1b). Maxillae longer than wide, anteriorly broad and scopulate (Fig. 1c). Labium vase-shaped, broad medially, narrowing anteriorly and posteriorly concave, scopulate (Fig. 1c). Sternum elongate, anteriorly wide, pointed behind, clothed with spines and spine-like hairs (Fig. 1d). Legs long and slender, clothed with spines and hairs and with black patches; leg formula 1234 and the measurements (mm) of different leg segments are shown in Table 1.

Table 1. Measurements (mm) of different leg segments of C. formosus Thorell

\begin{tabular}{lllllll}
\hline Leg & Femur & Patella & Tibia & Metatarsus & Tarsus & Total \\
\hline I & $5.00 / 5.00$ & $1.00 / 1.00$ & $2.80 / 2.80$ & $2.20 / 2.20$ & $1.50 / 1.50$ & $12.50 / 12.50$ \\
II & $3.00 / 3.00$ & $1.20 / 1.20$ & $2.50 / 2.50$ & $2.50 / 2.50$ & $1.50 / 1.50$ & $10.70 / 10.70$ \\
III & $2.00 / 2.00$ & $1.00 / 1.00$ & $1.50 / 1.50$ & $1.50 / 1.50$ & $0.70 / 0.70$ & $6.70 / 6.70$ \\
IV & $2.00 / 2.00$ & $0.50 / 0.50$ & $1.50 / 1.50$ & $1.00 / 1.00$ & $0.80 / 0.80$ & $5.80 / 5.80$ \\
\hline
\end{tabular}

Abdomen: Longer than wide, wider at anterior $2 / 3^{\text {rd }}$; dorsum decorated; epigyne as in Fig. 1e.

Distribution: Bangladesh: Bagerhat, Faridpur, Jhenidah, Jessore, Khulna; India; Indonesia; Myanmar; Sumatra ( Tikader 1980, Song and Zhu 1997 ).

\section{Camaricus chayani nov. sp. (Figs 2a-e)}

Material examined: Holotype: Female, Bagerhat, 12. IX. 1992, Coll. V. Biswas. Paratype: 1 female, Faridpur, 3.III. 1993, Coll. V. Biswas.

General: Cephalothorax red brown; legs greenish; abdomen brown. Total body length (holotype) $6.10 \mathrm{~mm}$. Carapace $2.40 \mathrm{~mm}$ long, $2.00 \mathrm{~mm}$ wide; abdomen $3.70 \mathrm{~mm}$ long and $3.00 \mathrm{~mm}$ wide.

Cephalothorax: Broad, high, wider at both ends, covered with fine hairs, anteriorly covered with brown band. Eyes pearly white, dissimilar; anterolateral eyes larger, others similar, each ringed with black basal band; both row of eyes recurved, posterior row slightly longer. Chelicerae brown, strong, each of inner and outer margins with 1 strong tooth (Fig. 2b). Maxillae brown, longer than wide, anteriorly broad and scopulate (Fig. 2c). Labium brown, pot-like, scopulate 


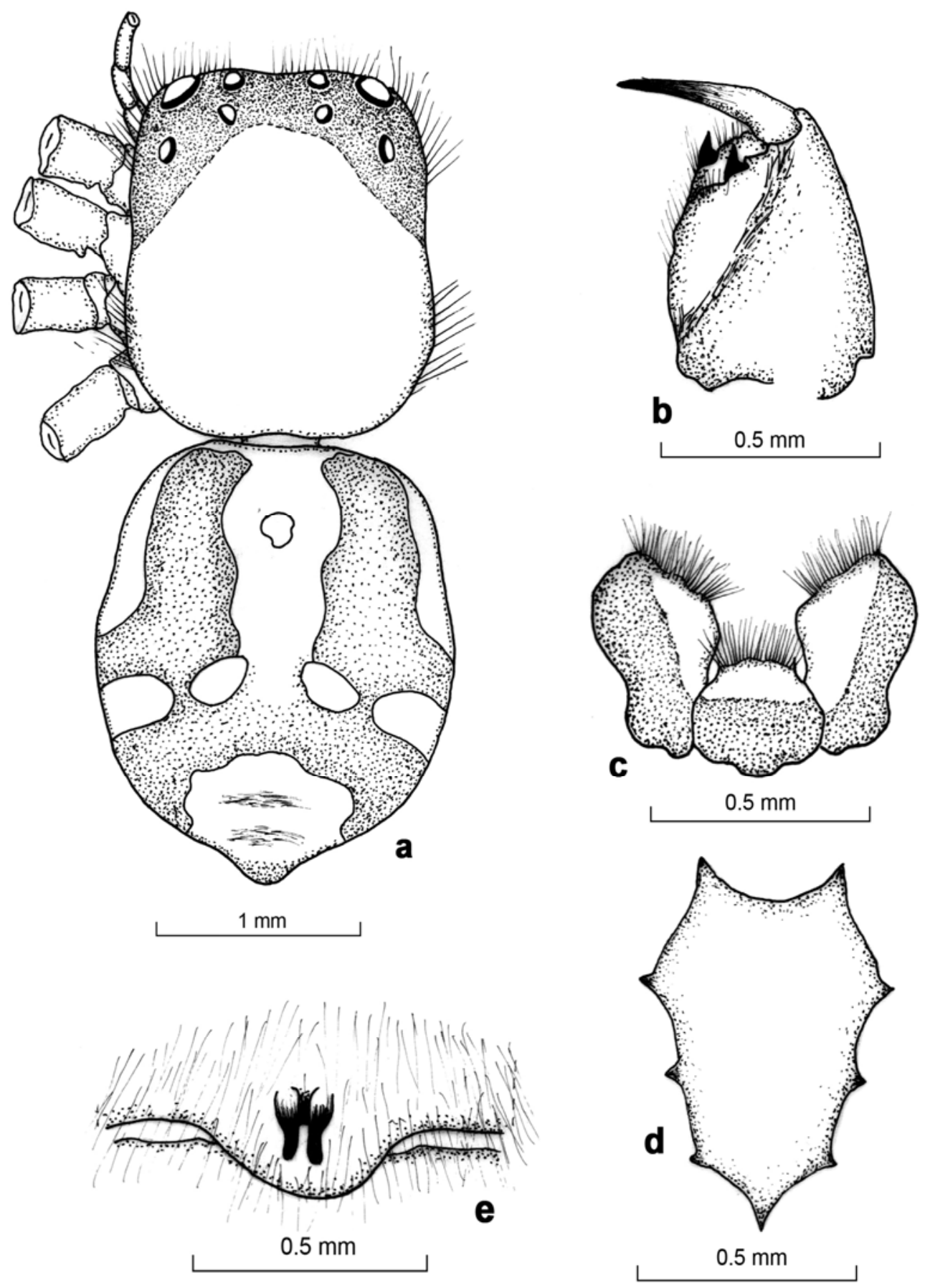

Fig. 2. Camaricus chayani nov.sp. a. Dorsal view; b. Chelicerae; c. Maxillae and labium; d. Sternum; e. Epigynum. 

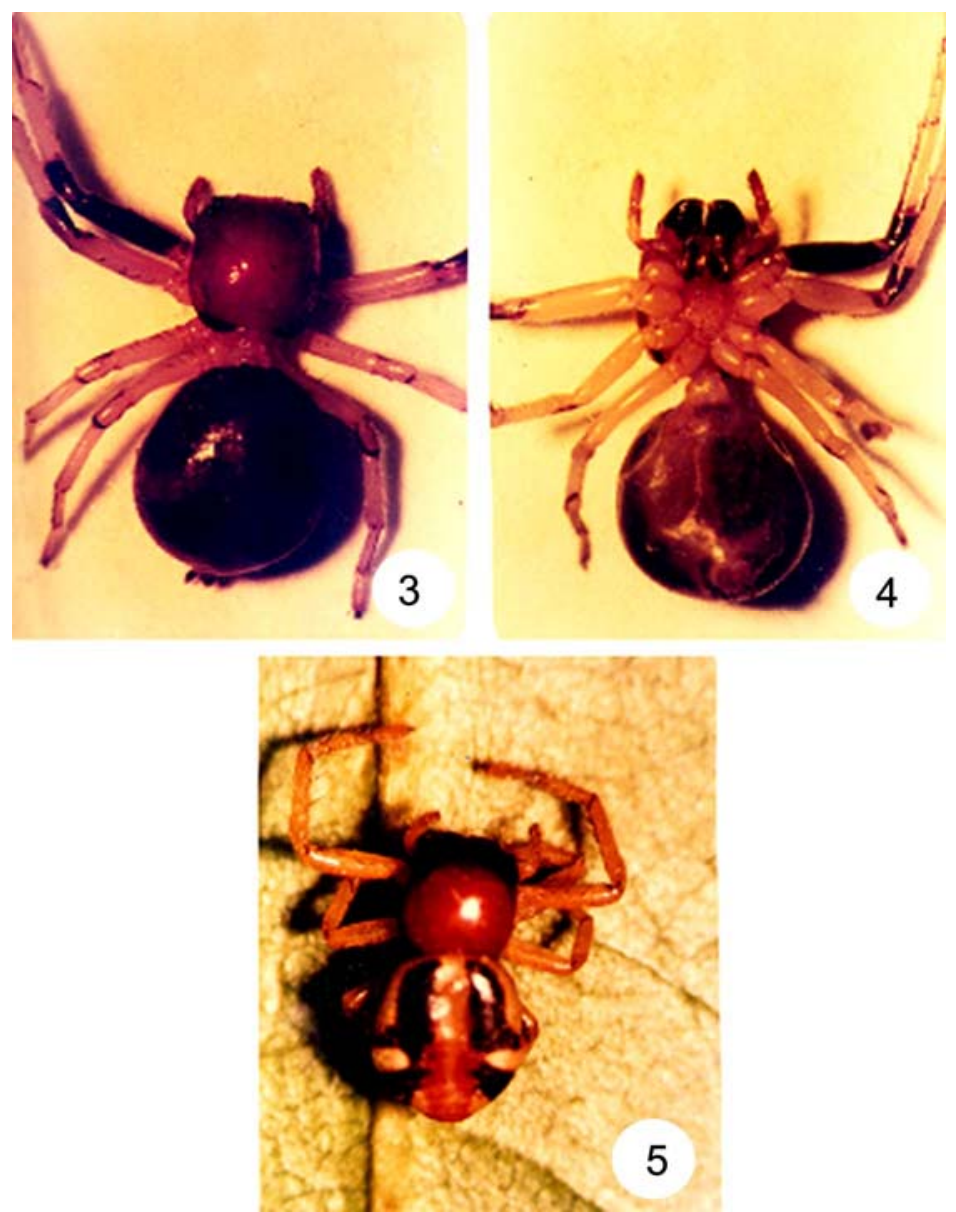

Figs 3-5. 3. Camaricus formosus Thorell (dorsal view); 4. C. formosus (ventral view); 5. Camaricus chayani nov.sp. (dorsal view).

anteriorly (Fig. 2c). Sternum elongate, clothed with fine hairs, narrowing posteriorly with a pointed tip (Fig. 2d). Legs long and slender, leg formula 1423 and the measurements $(\mathrm{mm})$ of different parts are shown in Table 2.

Table 2. Measurements (mm) of different leg segments of C. chayani nov. sp.

\begin{tabular}{lllllll}
\hline Leg & Femur & Patella & Tibia & Metatarsus & Tarsus & Total \\
\hline I & $1.50 / 1.50$ & $0.50 / 0.50$ & $1.50 / 1.50$ & $1.00 / 1.00$ & $0.80 / 0.80$ & $5.30 / 5.30$ \\
II & $1.00 / 1.00$ & $0.50 / 0.50$ & $1.40 / 1.40$ & $1.00 / 1.00$ & $0.80 / 0.80$ & $4.30 / 4.30$ \\
III & $1.00 / 1.00$ & $0.30 / 0.30$ & $0.80 / 0.80$ & $0.50 / 0.50$ & $0.50 / 0.50$ & $3.10 / 3.10$ \\
IV & $1.30 / 1.30$ & $0.50 / 0.50$ & $1.00 / 1.00$ & $0.90 / 0.90$ & $0.90 / 0.90$ & $4.60 / 4.60$ \\
\hline
\end{tabular}


Abdomen: Broad, longer than wide; dorsum decorated with black bands ; ventrally with pale brown longitudinal patch extending from the epigastric furrow to the spinnerets; epigyne as in Fig. 2e.

Distribution: Bangladesh: Dasani and Kochua, dist. Bagerhat, Agricultural Diploma Institute, dist. Faridpur (type-localities).

Etymology: The species is named after the name of nephew of first author (Vb) Chayan Biswas.

Remarks: Following the key provided by Tikader (1980), species C. chayani nov. sp. appears to be the closest ally of C. formosus Thorell but can be separated out because of the following: 1. Cephalothorax without any longitudinal fovea. 2. Anterolateral eyes larger. 3. Cheliceral margins each with 1 tooth. 4. Labium globular. 5. Sternum elongate and 6. The typical epigynum.

\section{DISCUSSION}

The present paper describes two species of the genus Camaricus Thorell of which one species C. chayani n. sp. is identified as new to science and another one $C$. formosus Thorell is for the first time recorded from the area of present study. Both the species are common members of the gardens and forests of Bangladesh.

All the species of this study are recorded from the south-western districts e.g. Bagerhat, Khulna, Faridpur, Jhenidah and Jessore. It proves that majority of the species of the genus are concentrated in the south-western region of the country. In the world fauna, majority of the species of this genus are distributed to the tropical region mainly in the South Asian countries (Tikader 1980; Song and Zhu 1997, Platnick 2016 ).

Species of the genus Camaricus cannot spin any web. However, they can show a remarkable degree of camouflage or mimicry on the flowers of the garden and stay there for preying the nectaring and pollinating insects. Beside this, they also consume harmful or pest insects in the garden crops and thus they play a potential role as a bio-control agent of pest insects of the garden and forests of Bangladesh.

During the field collection of this study, it was found that the population of C. formosus Thorell was maximum in number than C. chayanin. It was also observed that both the species become very active during shiny sunlight on the day and are staying spreading the legs on the flower and green leaves of plants.

Acknowledgements: The authors are grateful to Dr. S.C. Majumder, Scientist - SD, Zoological Survey of India, Kolkata, for confirming the identity of the species and the Head, Department of Zoology, University of Calcutta, for providing the laboratory facilities during the study. 


\section{LITERATURE CITED}

BARRION, A.T. and LITSINGER, J.A. 1995. Riceland spiders of South and Southeast Asia.CABI IRRI, $700 \mathrm{p}$.

BEGUM, A. and BISWAS, V. 1997. A list of spider fauna of Barisal division, Bangladesh (Araneae :Arachnida ). Bangladesh j. Zool., 25 (2): 207-210.

BISWAS, V. 2009. In: Ahmed (ed.): Flora and Fauna of Bangladesh, Arachnida 18(1), Asiatic Soc. Banglad4esh, $437 \mathrm{p}$.

BISWAS, V. and RAYCHAUDHURI, D. 2003. A new species of spider of the genus Tibellus Simon (Araneae : Thomisidae) from Jhenidah, Bangladesh. J. Bombay Nat. Hist. Soc. 100(1): 84-86.

BISWAS, V., BEGUM, A., KAMAL, N. Q. and KHAN, H. R. 1993. A preliminary study on the ricefield spiders of Jhenidah, Bangladesh. Bangladesh J. Zool. 21(1): 85-92.

CHEN, Z. F. and ZHANG, Z. H. 1991. Fauna of Zhejiang, Araneida. Zhejiang Sci. \& Tech. Pub. House $356 \mathrm{p}$.

CHOWDHURY, S. H. and NAGARI, S. 1981. Rice-field spiders from Chittagong. Proc. Zool. Soc. Bangladesh: $53-72$.

CHOWDHURY, S. H. and PAL, S. K. 1984. Further report on rice-field spiders from Bangladesh. Chittagong Univ. Studies, II 8(1): 25-39.

DONDALE, C. D. and REDNER, J. H. 1978. Crab spiders of Canada and Alaska (Araneae : Philodromidae and Thomisidae ). The insects and Arachnida of Canada, Part- 5: 255 p.

GAJBE, U. A. and GAJBE, P. 2000. A new species of spider of the genus Thomisus Walckenaer ( Araneae : Thomisidae ) from Madhya Pradesh, India. Rec. Zool. Surv. India 98(2 ): 55-57.

KESWANI, S., HADOLE, P. and RAJORIA, A. 2012. Checklist of spiders (Arachnida : Araneae) from India. Indian J. Arachnol. 1(1): 129.

KIM, J. P. and GWON, S. P. 2001. A revisional study of the spider family Thomisidae Sundevall , 1833 (Arachnida : Araneae) from Korea. Korean Arachnol. 17: 13-78.

KIM, S. T. and LEE, S. Y. 2012. Invertebrate Fauna of Korea (Arthropoda : Arachnida : Araneae : Thomisidae ), Thomisid Spiders, National Institute of Biological Resources 21(9): 1-88.

LINCOLN, R. J. and SHEALS, J. G. 1979. Invertebrate Animals collection and preservation. British Museum ( Natural History ), London. 150 p.

MAJUMDER, S. C. 2005. Studies on some spiders from eastern coastal region of India. Mem. Zool. Surv. India 20(3): 1-57.

NAMKUNG, J. 2003. The Spiders of Korea. $2^{\text {nd }}$ ed., Kyo-Hak Publishing Co. 648 p.

OKUMA, C., KAMAL, N. Q., HIRASHIMA, Y., ALAM, Z. and OGATA, T. 1993. Illustrated Monographon the rice-field spiders of Bangladesh. IPSA-JAICA, Salna, Gazipur, p. 93.

ONO, H. 1988. A revisional study of the spider family Thomisidae (Arachnida : Artaneae ) of Japan. Bull. Nat. Sci. Mus, Tokyo. pp. 1-252.

PAIK, K. Y. 1978. Illustrated Flora and Fauna of Korea. 21 : 1-546.

PLATNICK, N. I. 1997. Advances in Spider Taxonomy 1992-1995. A supplement to Brignoli's A Catalogue of Araneae described between 1940-1981. Mancester University Press. 976 p.

PLATNICK, N. I. 2016. World spider Catalog, version 16.0. American Museum of Natural History. on line at http ://research.amnh.org/entomology/ spiders/ catalog/ index.html.( accessed on 07th August, 2016).

POCOCK, R. I. 1900. The Fauna of British India, Arachnida. Taylor \& Francis, London. 279 p.

SAHA, S. and RAYCHAUDHURI, D. 2007. Crab spiders (Araneae : Thomisidae ) of Jaldapara Wildlife Sanctuary, Jalpaiguri, West Bengal. J. Bombay Nat. Hist. Soc. 104(1): 58-63. 
SCHICK, R. X. 1965. The crab spiders of California (Araneae : Thomisidae ). Bull. Amer. Mus. Nat. Hist. 129(1): 1-180.

SEN, S., DHALI, D. C., SAHA, S. and RAYCHAUYDHURI, D. 2015. Spiders (Araneae : Arachnida) of reserve forests of doars : Gorumara National Park, Chapramari Wildlife Sanctuary and Mahananda Wildlife Sanctuary. World Scientific News 20: 1-339.

SONG, D. X. and ZHU, M. S. 1997. Fauna Sinica, Thomisidae, Vol. 35, Science press, Beijing. 259 p.

SONG, D. X., ZHU, M. S. and CHEN, J. 1999. The Spiders of China.Hebei Sci. Tech. Pub. House, 640 p.

TIKADER, B. K. 1980. Fauna of India, Thomisidae, 1 (1), Zoological Survey of India. 247 p.

TIKADER, B. K. 1987. Hand Book of Indian Spiders. Director, Zoological Survey of India, Kolkata, $251 \mathrm{p}$.

TIKADER, B. K. and BISWAS, B. 1981. Spider fauna of Calcutta and Vicinity.Rec. zool. Surv. India, Occ. Pap. No. 30: 1-149.

YAGINUMA, T. 1986. Spiders of Japan in colour (new ed.). Hoikusha Pub. Co. Ltd., Osaka. p. 305.

ZHAO, J. Z. 1993. Spiders in the Cotton Fields in China. Wuhan Press, China. 552 p.

(Manuscript received on 20 November, 2016; revised on 31 December, 2016) 